\title{
PENINGKATAN KETERAMPILAN GURU MATEMATIKA SMP DALAM PENGELOLAAN DISTANCE LEARNING SEBAGAI PERLUASAN RAGAM PEMBELAJARAN DI KABUPATEN JEMBER
}

\author{
Auli Damayanti ${ }^{1}$, Abdulloh Jaelani ${ }^{1 *}$, Cicik Alfiniyah ${ }^{1}$ \\ ${ }^{1}$ Departemen Matematika, Fakultas Sains dan Teknologi, Universitas Airlangga, Surabaya, Indonesia \\ *Email: abdjae@fst.unair.ac.id
}

\begin{tabular}{ll}
\hline Informasi Artikel & Abstrak \\
\hline Kata kunci: & $\begin{array}{l}\text { Pandemik Covid-19 yang terjadi pada tahun 2020 telah berdampak secara } \\
\text { signifikan pada semua bidang, salah satunya bidang pendidikan. Guru }\end{array}$ \\
Pandemi Covid-19, & $\begin{array}{l}\text { tidak lagi bisa melakukan proses pembelajaran secara tatap muka di } \\
\text { kelas. Oleh karena itu guru dituntut untuk dapat melakukan proses belajar } \\
\text { Distance learning, } \\
\text { Mongajar secara daring. Pada kegiatan pengabdian kepada masyarakat ini } \\
\text { bertujuan untuk meningkatkan keterampilan guru dalam mengelola }\end{array}$ \\
Diterima: $17-11-2021$ & $\begin{array}{l}\text { distance learning menggunakan Moodle. Rangkaian kegiatan diawali } \\
\text { dengan proses instalasi moodle, proses perancangan pembelajaran, }\end{array}$ \\
Disetujui: 10-01-2022 & $\begin{array}{l}\text { pembuatan konten, pembuatan forum interaksi, serta manajemen } \\
\text { pengelolaan (desain, fitur, dan lain-lain) serta evaluasi. Peserta }\end{array}$ \\
Dipubikasikan: 28-01- & $\begin{array}{l}\text { pengabdian kepada masyarakat ini adalah guru Matematika SMP yang } \\
\text { tergabung dalam MGMP Matematika wilayah barat Kabupaten Jember } \\
\text { 2022 }\end{array}$ \\
& $\begin{array}{l}\text { sebanyak 30 orang dan semuanya dapat mengikuti pelatihan dari awal } \\
\text { sampai akhir. Selain itu, peserta mampu membuat dan mengembangkan } \\
\text { e-learning beserta kontennya menggunakan Moodle. Lebih lanjut } \\
\text { diperolah peningkatan ketrampilan dan pengetahuan guru dalam } \\
\text { mengelola distance learning menggunakan Moodle sebesar 33,09\%. }\end{array}$ \\
\cline { 2 - 2 } & Abstract \\
\hline
\end{tabular}

\section{Keywords :}

Covid-19 pandemic, Distance learning, Moodle
The Covid-19 pandemic that occurred in 2020 has had a significant impact on all fields, one of which is education. Teachers can no longer carry out the face-to-face learning process in class. Therefore, teachers are required to be able to carry out the teaching and learning process online. This community service activity aims to improve teacher skills in managing distance learning using Moodle. The series of activities began with the Moodle installation process, the learning design process, content creation, the interaction forum, management (design, features, etc.), and evaluation. Participants of this community service are 30 junior high school mathematics teachers who are members of the Mathematics MGMP in the western region of Jember Regency, totaling 30 participants, and all of them can take part in the training from start to finish. In addition, participants were able to create and develop e-learning and its content using Moodle. Furthermore, an increase in the skills and knowledge of teachers in managing distance learning using Moodle was obtained by $33.09 \%$. 


\section{PENDAHULUAN}

Era Revolusi Industri 4.0 telah mendistrupsi hampir seluruh aktivitas manusia dalam berbagai bidang seperti pendidikan, ekonomi, sosial, dan politik. Tantangan 5 tahun ke depan Revolusi Industri 4.0 di antaranya adalah beberapa bidang pekerjaan akan digantikan oleh mesin/ otomatisasi dan integrasi teknologi. Namun demikian kemampuan analitik nonrutin dan interaktif nonrutin tidak akan tergantikan oleh mesin. Menurut Manyika et al., (2013) sebanyak 50\% perusahaan meyakini bahwa proses otomatisasi yang terjadi akan menurunkan jumlah pegawai mereka sebesar 800 juta pekerja di seluruh dunia. Menteri Ketenagakerjaan Republik Indonesia menyatakan bahwa diperkirakan "akan ada 23 juta jenis pekerjaan yang terdampak sistem otomatisasi hingga akhir 2030 mendatang" (Farasonalia, 2019).

Hal ini memacu semua pihak tak terkecuali Pemerintah untuk menggagas agar Indonesia dapat berkontribusi aktif dalam persaingan global di era revolusi industri 4.0. Kualitas sumber daya manusia yang memadai dan adaptif terhadap perubahan menjadi sasaran utama bidang pendidikan. Otomatisasi sangat membutuhkan penguasaan teknologi terkini, kreativitas, dan inovasi di berbagai sektor kehidupan.

Adanya pandemik global Covid-19 ini telah berdampak secara signifikan pada bidang ekonomi, perdagangan, sosial, dan pendidikan. Khusus di bidang pendidikan, keberlangsungan proses pembelajaran secara normal dimana siswa dan guru bertemu/ bertatap muka secara langsung di kelas (pembelajaran klasikal) tidak memungkinkan untuk dilakukan. Hal ini disebabkan penyebaran virus corona akan semakin meluas pada situasi keramaian dan kerumunan banyak orang. Kebijakan larangan berkumpulnya banyak orang mengakibatkan proses pembelajaran tidak lagi dilakukan dengan tatap muka langsung antara siswa dan guru, melainkan harus menggunakan media dengan memanfaatkan teknologi terkini melalui pembelajaran daring (online). Pandemik Covid-19 mengakibatkan perubahan sangat signifikan dalam bentuk pembelajaran dari tatap muka langsung menjadi pembelajaran jarak jauh (distance learning). Menteri Pendidikan dan Kebudayaan Republik Indonesia menyatakan bahwa "meluasnya wabah Covid-19 menjadi momentum bagi para pendidik untuk mengembangkan metode pembelajaran jarak jauh" (Makdori, 2020).

Kebijakan Menteri Pendidikan dan Kebudayaan tentang penggunaan metode pembelajaran jarak jauh sontak membuat banyak pihak khususnya guru sangat terkejut. Bukan hanya karena belum terbiasa, tetapi juga mayoritas guru belum memahami bagaimana mengelola dan mengembangkan pembelajaran jarak jauh (distance learning) tersebut. Fakta di lapangan menunjukkan bahwa guru belum memiliki pengetahuan yang memadai tentang distance learning, artinya kesiapan dan kemampuan guru untuk mengelola distance learning masih belum optimal dan perlu ditingkatkan. 
(Kaplan \& Haenlein (2016) mengatakan bahwa "Distance learning is the education of students who may not always be physically present at a school". Hal ini berarti bahwa dalam distance learning siswa tidak harus berada di dalam kelas di sekolah. Oleh karena itu, distance learning merupakan proses belajar mengajar yang terorganisasi untuk menjembatani tatap muka antara siswa dan guru dengan memanfaatkan teknologi tanpa mengharuskan guru dan siswa bertatap muka secara langsung sebagaimana pembelajaran klasikal. Arsyad (2013) menyatakan bahwa media pembelajaran merupakan salah satu sumber belajar yang baik menggunakan perangkat keras maupun perangkat lunak. Oleh karena itu, dalam mengimplementasikan distance learning guru juga dituntut untuk menggelola pembelajaran agar dapat membantu siswa memahami materi sebagaimana tatap muka secara langsung di kelas.

Berdasarkan hasil evaluasi pelaksanaan pengmas yang telah dilakukan pada tahun 2019 di lokasi yang sama di Kabupaten Jember terungkap bahwa 3 (tiga) kebutuhan pelatihan lanjutan dengan persentase terbesar yang dibutuhkan oleh peserta adalah (i) Pembelajaran berbasis teknologi informasi (22,92\%); (ii) Penilaian aspek keterampilan dalam pembelajaran; dan (iii) Peningkatan kemampuan penulisan karya ilmiah (Jaelani et al., 2019). Disamping itu, berdasarkan analisis situasi, teridentifikasi permasalahan yang dihadapi mitra terkait sebagai berikut :

1) Adanya pandemik global Covid-19 menuntut guru untuk melakukan proses pembelajaran secara daring dengan memanfaatkan memanfatkan teknologi dan menggelola distance learning menggunakan Learning Management Systems (LMS)

2) Rendahnya produktivitas guru dalam memanfaatkan teknologi untuk mengembangkan sumber belajar dalam proses belajar mengajar.

3) Guru kurang memahami konsep distance learning.

4) Kemampuan guru dalam membuat media berbasis virtual perlu ditingkatkan, baik sisi penguasaan materi maupun teknis penyusunan.

Berdasarkan permasalahan di atas penggelolahan distance learning menggunakan Learning Management Systems (LMS) Moodle. Ismail (2019) menyatakan “ Learning management system, the basic description is a software application that can automatically manage, track and report training events". Oleh karena itu Moodle sebagai salah satu LMS dipilih menjadi alternatif ragam pembelajaran sebagai pengayaan dan solusi bagi guru terlebih di tengah situasi pandemik Covid-19. Solusi ini untuk memberikan bekal kepada guru dalam mengelola distance learning dengan meningkatkan produktivitas dan memaksimalkan pemanfaatan teknologi informasi serta aplikasi komputer berbasis multimedia. Moodle merupakan open source learning platform yang banyak digunakan dan paling popular saat ini dan mempunyai banyak user (Darmawan, 2014). Moodle merupakan aplikasi web yang tidak berbayar, pengoperasiannya cukup mudah, dan banyak fitur yang dapat dimanfaatkan oleh user. Dengan kondisi di atas, diharapkan guru tidak akan mengalami 
kesulitan dalam mengembangkan distance learning nantinya, sehingga pelaksanaannya tidak akan mengalami kendala baik sisi biaya, pengoperasian, maupun pembuatan konten pembelajaran secara mandiri. Hal ini sangat penting dan tentunya menjadi salah satu pertimbangan aspek keberlanjutan sebuah kegiatan.

Kegiatan ini difokuskan pada pelatihan peningkatan keterampilan guru matematika SMP dalam pengelolaan distance learning menggunakan Learning Management Systems (LMS) sebagai perluasan ragam pembelajaran. Pelatihan ini sekaligus menjawab tantangan penggunaan teknologi informasi menyikapi kondisi-kondisi "luar biasa" seperti pandemik virus saat ini. Sedangkan tujuannya adalah memberikan bekal yang memadai kepada guru dalam mengelola distance learning menggunakan Learning Management Systems (LMS) agar dapat dimanfaatkan dan diterapkan pada situasi yang kondusif.

\section{METODE}

Kegiatan pengmas ini dikemas dalam bentuk pelatihan instalasi Moodle, pengembanagan desain Moodle, disertai praktik langsung, penugasan, dan evaluasi. Pemberian materi tentang pengelolaan distance learning dikemas dalam bentuk pelatihan selama 2 hari yang di dalamnya juga diberikan tugas kelompok (dengan pendampingan oleh instruktur) kemudian didiskusikan dalam kelas paralel untuk mendapat umpan balik dari peserta lain. Dengan pengetahuan yang didapat selama pelatihan, pendampingan oleh instruktur dalam mengerjakan tugas, serta kemudahan pengoperasian Moodle, diharapkan guru dapat mengembangkan distance learning secara mandiri tanpa menemui kendala/kesulitan yang berarti pada sekolahnya masing-masing.

Sasaran kegiatan ini adalah para guru matematika SMP di Kabupaten Jember yang berjumlah 30 orang yang tergabung dalam Musyawarah Guru Mata Pelajaran (MGMP) Matematika wilayah barat Kabupaten Jember.

Seluruh rangkaian kegiatan yang bersifat tatap muka dilaksanakan di SMP Negeri 2 Tanggul dan yang tidak tatap muka dilakuna menggunakan zoom atau whatsapp. Adapun kegiatan dalam pelaksanaan diberikan secara bertahap, yaitu tahap 1, Pelatihan instalasi Moodle sebagai salah satu Learning Management System (LMS); tahap 2, pelatihan pengembangan manajemen kelas dan manajemen assessment menggunakan Moodle; tahap 3, konsultasi dan pendampingan oleh narasumber. Untuk tahap 1 dan 3 dilakukan secara daring sedangkan tahap 2 dilakukan secara luring.

\section{HASIL DAN PEMBAHASAN}

Pada kegiatan pengabdian masyarakat ini terdapat 3 tahapan kegiatan yaitu tahap I adalah pelatihan instalasi Moodle, tahap II adalah pelatihan pengembangan desain konten Moodle, dan tahap III adalah proses konsultasi dan pendampingan oleh narasumber dari tugas yang diberikan panitia pengmas kepada peserta. 
Tahap I dilakukan secara daring hari Rabu tanggal 9 September 2020, mulai pukul 08.00 sampai selesai yang diikuti sebanyak 30 peserta. Setelah diberikan materi software Moodle dan langkahlangkah pengintalannya, peserta menginstal pada labtopnya masing-masing sesuai dengan tahapan yang telah disampaikan. Proses instalasi masih didampingi narasumber maupun tim pelaksana lainnya hingga proses install berhasil.

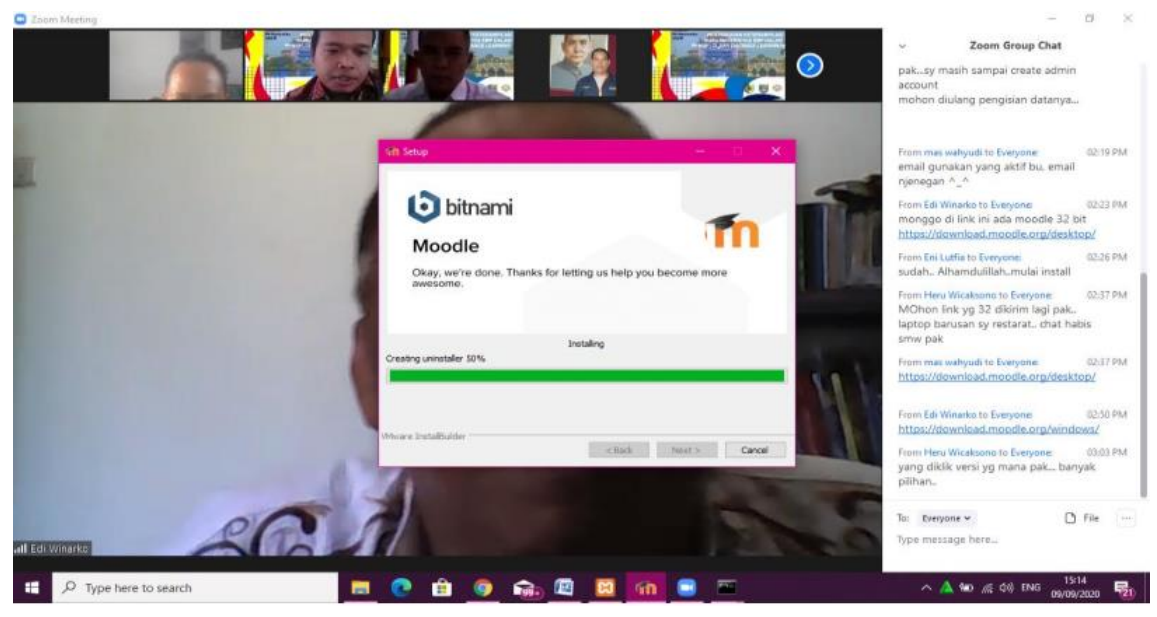

Gambar 1. Pelatihan Proses Penginstalan Sofware Moodle

Tahap II kegiatan pengabdian masyarakat adalah pelatihan pengembangan desain konten pada Moodle. Pelatihan ini dilaksanakan secara luring (tatap muka) pada tanggal 12 September 2020 di SMP Negeri 2 Tanggul Jember dengan menerapkan protocol kesehatan (kewajiban penggunaan masker, face shield dan selalu mencuci tangan). Pada pelatihan desain konten pada Moodle ini, peserta diajarkan bagaimana mendesain konten Moodle, antara lain; pembuatan kelas, enroll student, unggah materi (file office, youtube, video, dll), pembuatan tugas/quis, pembuatan soal/bank soal, serta diskusi/interaksi. Proses pengisian konten Moodle yang ada, akan dilakukan secara mandiri oleh peserta yang merupakan bagian dari tugas individu peserta (tahap III).

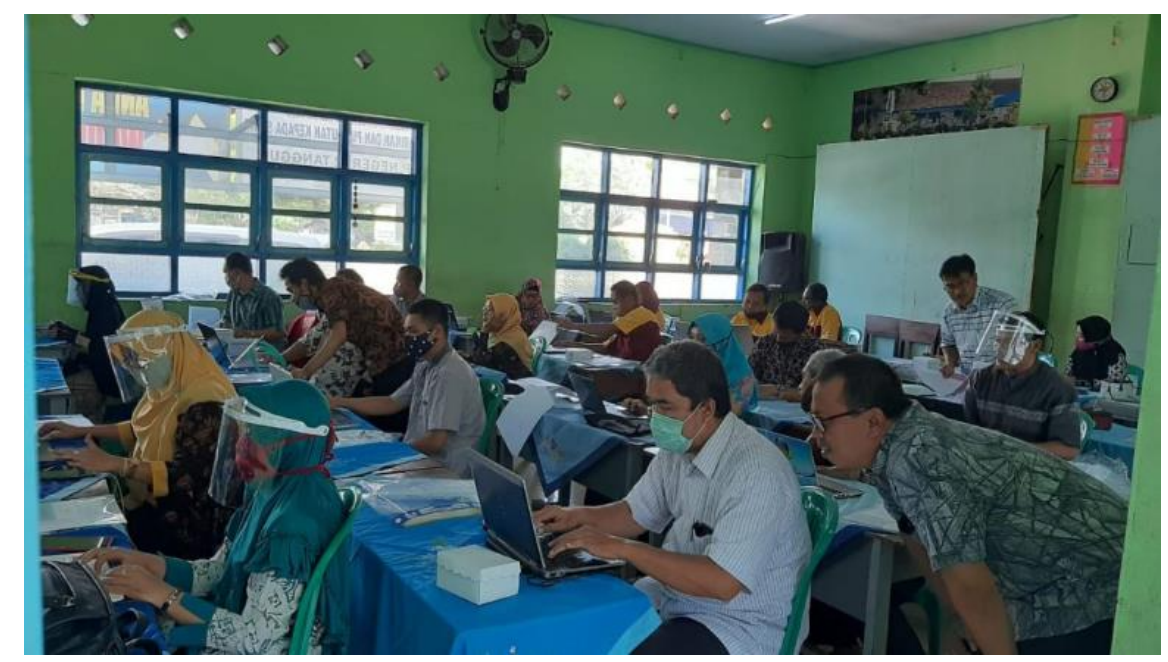

Gambar 2. Pelaksanaan Pelatihan Pembuatan Desain Kontek Moodle 
Tahap III dilaksanakan mulai tanggal 13 September - 10 November 2020, pada tahap ini peserta menyelesikan/melengkapai konten Moodle yang telah didesaian pada tahap II. Pada kegiatan ini tim pelaksana pengmas melayani konsultasi dan pendampingan peserta yang dilakukan via zoom atau whatsapp. Konsultasi dan pendampingan dilakukan sebagai tindak lanjut adanya penugasan terstruktur (individu) dengan hal ini tim pelaksana akan dapat memberikan masukan dan saran sehingga peserta dapat pengelolaan distance learning yang berkwalitas. Sehingga nantinya peserta bisa mengembangkan disekolahnya secara mandiri.

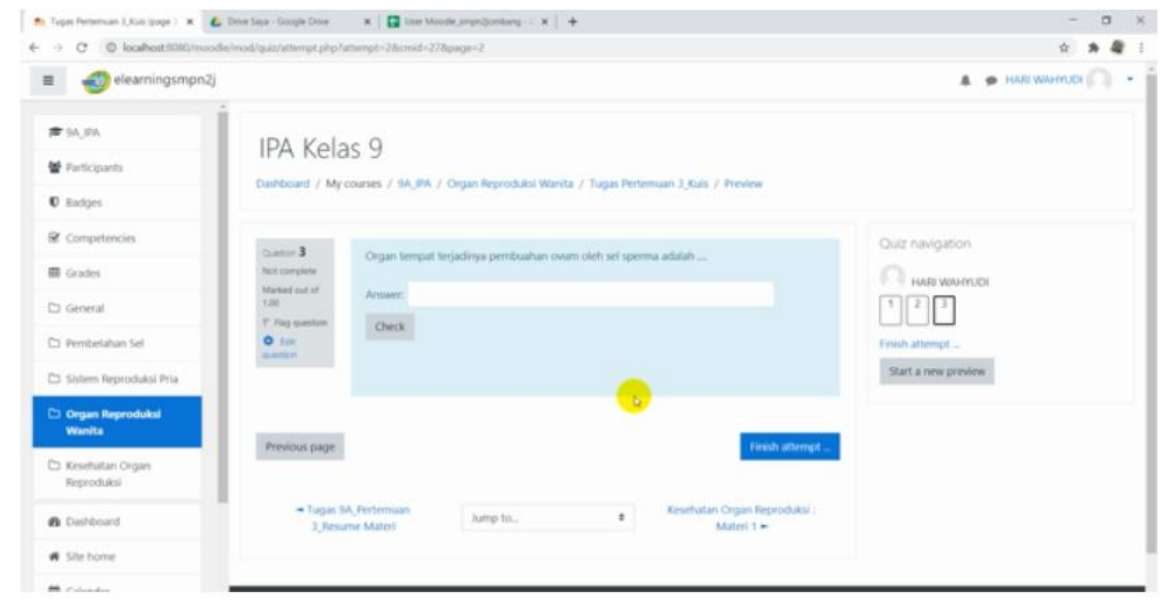

Gambar 2. Hasil LMS Peserta Pengabdian

Sedangkan hasil analisis soal pretes maupun postes dalam kegiatan pengabdian ini sebagai berikut

Tabel 1. Hasil Pretes dan Postes

\begin{tabular}{lrr}
\hline & Pretest & Postest \\
\hline Mean & 63.32 & 84.28 \\
Standard Error & 3.26 & 1.97 \\
Standard Deviation & 17.86 & 10.84 \\
Sample Variance & 319.24 & 117.59 \\
Minimum & 28.57 & 71.42 \\
Maximum & 85.71 & 100 \\
Count & 30 & 30 \\
\hline
\end{tabular}

Berdasarkan Tabel 1, nilai minimum dan maksimum pada saat pretes adalah 28,57 dan 85,71 dengan rerata 63,33 dan standar deviasinya sebesar 17,86. Sedangkan hasil postes, nilai minimum dan maksimum adalah 71,42 dan 100 dengan rerata 84,28 dan standar deviasinya sebesar 10,84. Hal ini berarti berdasarkan hasil reratanya terjadi peningkatan sebesar 33,09\%.

\section{KESIMPULAN}

Dari seluruh rangkaian kegiatan pengabdian kepada masyarakat yang telah terlaksana, dapat diambil kesimpulan sebagai berikut: 
1. Penggelolaan distance learning ini dapat membatu peserta untuk mengembangkan e-learning beserta kontennya menggunakan Learning Management Systems (LMS) Moodle.

2. Peningkatan pemahaman peserta dalam penggelolahan distance learning menggunakan Learning Management Systems (LMS) Moodle sebesar 33,09\%

\section{UCAPAN TERIMAKASIH}

Penulis mengucapkan terima kasih kepada Universitas Airlangga.artikel ini ditulis sebagai output dari program hibah pengabdian masyarakat yang didanai oleh Universitas Airlangga.

\section{DAFTAR PUSTAKA}

Arsyad, A. (2013). Media Pembelajaran. Jakarta: Rajawali Pres.

Darmawan, A. (2014). Pemilihan Sistem Learning Management System (LMS) Metode AHP Menggunakan Criterium Decision Plus 3.0. Faktor Exacta, 7(3), 260-270.

Farasonalia, R. (2019). Menteri Tenaga Kerja: 23 Juta Pekerja Indonesia Terdampak Otomatisasi di Era Revolusi Industri 4.0. Https://Regional.Kompas.Com/ Read/2019/11/26 /16501841/MenteriTenaga-Kerja-23-Juta-Pekerja-Indonesia-Terdampak-Otomatisasi-Di-Era (Diakses 12 Maret 2020).

Ismail, S. (2019). Virtual Lab. SSRN Electronic Journal. https://doi.org/10.2139/ssrn.3328427

Jaelani, A., Kuswandari, I., \& Alfiniyah, C. (2019). Peningkatan Profesionalitas Guru Dalam Penyusunan Evaluasi Berbasis Thinking Analysis Bagi Guru Matematika. Jurnal Penamas Adi Buana, 3(2), 51-56. https://doi.org/10.36456/penamas.vol3.no2.a2221

Kaplan, A. M., \& Haenlein, M. (2016). Higher education and the digital revolution: About MOOCs, SPOCs, social media, and the Cookie Monster. Business Horizons, 59(4), 441-450. https://doi.org/10.1016/j.bushor.2016.03.008

Makdori, Y. (2020). Nadiem: Wabah Covid-19 Momentum Guru Kembangkan Pembelajaran Jarak Jauh. Https://Www.Liputan6.Com/News/Read/4210349/ Nadiemwabah-Covid-19-MomentumGuru-Kembangkan-Pembelajaran-Jarak-Jauh, (Diakses 20 April 2020).

Manyika, J., Chui, M., Peter Groves, Farrell, D., Kuiken, S. Van, \& Doshi, E. A. (2013). The McKinsey Global Institute. In McKinsey Global Institute. 